\title{
JOB SATISFACTION AND AFFECTIVE COMMITMENT: A STUDY OF EMPLOYEES IN THE TOURISM INDUSTRY IN SARAWAK, MALAYSIA
}

\author{
LEW TEK YEW \\ Curtin University of Technology
}

\begin{abstract}
This study examines what motivates the employees involved in the tourism industry in Sarawak, Malaysia, their level of job satisfaction and the influence of job satisfaction on affective commitment. It also examines whether age moderates the abovementioned relationship. Tourism is a critical industry which accommodates an increasing number of visitors to Sarawak, positioning itself as the "Sarawak-More Than A Paradise" in the Asia Pacific region. Studies have confirmed that satisfied employees will be more committed to their organizations and offer high quality service to the customers. Hierarchical regression analysis was used to analyze the data of the study. The three most important factors to motivate employees are interesting work, job security and opportunities for advancement and development. Satisfaction towards 'salary' was found to have a significant positive relationship with affective commitment. Also, satisfaction towards supervision showed significant positive relationships with normative commitment. However, age did not moderate the relationships between job satisfaction and organizational commitment. The findings of this study provide valuable insights for the management of tourism-related organizations in Malaysia and the Asia Pacific region to create a motivated and committed workforce.
\end{abstract}

Keywords: Job Satisfaction, Affective Commitment

\section{INTRODUCTION}

Job satisfaction as a significant determinant of organizational commitment has been well documented in numerous studies (Porter et al., 1974; Mottaz, 1987; Williams and Anderson, 1991; Vanderberg and Lance, 1992; Knoop, 1995; Young, Worchel and Woehr, 1998; Testa, 2001). Hence, managers in today's organizations have placed great importance on the issue of job satisfaction of their employees. This is because employees who are satisfied are more likely to be committed to their organizations. These workers, in return, are more likely to take pride in organizational membership, believe in the goals and values of the organization and, therefore, exhibit higher levels of performance and productivity (Steinhaus and Perry, 1996).

The tourism industry is chosen for analysis of job satisfaction as it is a critical industry which accommodates an increasing number of visitors to Miri, proclaimed as a resort city of Malaysia on 20 May 2005. Tourism is also the second largest foreign exchange earner in Malaysia after manufacturing. Tourist arrivals reached new records of 13.3 million in 2002,

E-mail alew.tek.yew@curtin.edu.my 
generating USD6.8 billion in tourist receipts. In 2003, Malaysia received 10.6 million tourists despite the SARS outbreak and in the first four months of 2004, the number of tourists had reached 5.2 million, a 57\% increase compared to the corresponding period in 2003 (The Borneo Post, 26 June 2004). Meanwhile, out of the 10.6 million tourists who visited Malaysia in 2003, over 3 million visited Sarawak and Miri recorded over a million tourist arrivals (The Borneo Post, 26 June 2004). Moreover, the tourism industry is projected to generate a total revenue of about RM244 billion during the period of the $9^{\text {th }}$ Malaysian Plan (The Borneo Post, 5 July 2006). Hence, highly satisfied and committed employees in the tourism industry, delivering high quality service to tourists, are of paramount importance as they are often seen as an integral part of the service experience (Lovelock and Wright, 2002).

With reference to the services industry such as that of tourism, the link between job satisfaction of the employees and organization commitment has also been well demonstrated by the "service profit chain" which showed an explicit link between satisfied employees and loyalty to their employers and degree of productivity. As a result, employees will deliver high service quality and, in the process, enhance customer loyalty. In short, employee satisfaction can contribute to customer loyalty through a series of links referred to as the "service profit chain" (Heskett et al., 1994)

Nasurdin and Ramayah (2003) have cited several studies on the predictors of organizational commitment, using Malaysian subjects. They commented that there were very few studies that focused on the relationship between job satisfaction and organizational commitment. Moreover, there were very few studies about job satisfaction among hotel employees reported in the literature, examples being Simons and Enz (1995) and Siu et al. (1997) on what motivates hotel employees in the United States and Canada as well as Hong Kong respectively. However, these studies did not examine the relationship between job satisfaction and organizational commitment. Hence, the first and second objectives of this study are to determine what motivates hotel employees in Sarawak and then explore the relationship between job satisfaction and organizational commitment. In addition, earlier studies on organizational commitment (Meyer and Allen, 1984) suggested that older workers tend to be more committed to an organization since they are likely to experience greater satisfaction with their jobs. Hence, the third objective of this study is to explore the role of age as a moderator in the relationship between job satisfaction and organizational commitment.

The importance of analyzing and enhancing the level of job satisfaction and motivation among employees, especially in the service industry, was highlighted by a report in the New Straits Times (9 April 2005, p. 10). In a survey conducted by an international research firm, Taylor Nelson Sofres (TNS), of 600 urban adults, it showed that job hopping is a phenomenon that employers have to contend with. The report showed that $58 \%$ of currently employed adult Malaysians have worked for up to three companies in the past five years, with $23 \%$ indicating they intend to change employers within the next three years. Meanwhile, $74 \%$ of the younger employees have changed employers over the past five years while 39\% will change employers within the next two years. This report implies that 
organizations need to be more assertive to strengthen employees' job commitment and play a more active role in increasing job satisfaction and motivation among employees.

\section{OBJECTIVES OF THE STUDY}

Hence, the main objectives of this study are to:

- Identify the factors motivating employees in the tourism industry in Sarawak, according to Kovach's Ten Job-Related Factors (1946), and the relative ranking of these factors in terms of the degree of motivational importance.

- Determine the relationship between the level of job satisfaction and the level of affective commitment. Given that there are basically five useful dimensions of job satisfaction, namely, pay, promotion, supervision, co-workers and work itself (Smith, Kendall and Hulin, 1969), this study investigated the relationship between the level of satisfaction of each of the facets of job satisfaction and the level of affective commitment, a dimension of organizational commitment according to the revised Organizational Commitment Scales (Meyer, Allen and Smith, 1993).

- Examine whether the positive relationship between job satisfaction and affective commitment will differ according to the age level of the employees. This study also investigated whether the positive relationship between the level of satisfaction of each of the facets of job satisfaction and affective commitment will differ for younger and older employees.

The supplementary objective of this study is to investigate the relationship between each facet of job satisfaction, and continuance and normative commitment.

The following two hypotheses are developed from the second and third objectives:

H1: The higher the level of job satisfaction, the greater the level of affective commitment.

H1a: The higher the level of satisfaction with pay, the greater the level of affective commitment.

H1b: The higher the level of satisfaction with promotion, the greater the level of affective commitment.

H1c: The higher the level of satisfaction with supervision, the greater the level of affective commitment.

H1d: The higher the level of satisfaction with co-workers, the greater the level of affective commitment.

H1e: The higher the level of satisfaction with work itself, the greater the level of affective commitment. 
H2: The positive relationship between job satisfaction and affective commitment will differ according to age.

H2a: The positive relationship between the level of satisfaction with pay and affective commitment will be stronger for younger employees than older employees.

$\mathrm{H} 2 \mathrm{~b}$ : The positive relationship between the level of satisfaction with promotion and affective commitment will be stronger for younger employees than older employees.

$\mathrm{H} 2 \mathrm{c}$ : The positive relationship between the level of satisfaction with supervision and affective commitment will be stronger for younger employees than older employees.

H2d: The positive relationship between the level of satisfaction with co-workers and affective commitment will be stronger for younger employees than older employees.

H2e: The positive relationship between the level of satisfaction with work itself and affective commitment will be stronger for younger employees than older employees.

\section{JOB SATISFACTION}

Job satisfaction as a construct has been defined differently by various scholars. The term was first defined by Hoppock (1935) as a combination of psychological, physical and environmental circumstances that causes a person to say, "I am satisfied with my job". Among the most accepted definition of job satisfaction is by Locke (1969) who defines job satisfaction as a positive emotional feeling, a result of one's evaluation towards his job or his job experience by comparing between what he expects from his job and what he actually gets from it. Job satisfaction is the result of the interaction of the employees' values and his perception towards his job and environment (Locke, 1976).

Nasurdin and Ramayah (2003), citing the work of O'Reilly and Caldwell (1980), indicated that both task and organizational rewards contribute to job satisfaction. Task rewards are intrinsic rewards directly associated with the job such as interesting and challenging work, variety and opportunities to use one's skills. Organizational rewards are the tangible rewards that are visible to others such as pay, promotion and comfortable working conditions.

Hoppock (1935) forwarded a traditional approach to job satisfaction. Here, job satisfaction is a result of various factors in the working environment and if these factors are present, job satisfaction will arise, otherwise job dissatisfaction will emerge. The same factors will influence job satisfaction and job dissatisfaction. In contrast, Herzberg et al. (1959) distinguished the factors like work environment, pay and company policies that eliminate job dissatisfaction as the hygiene factors while the factors creating job satisfaction like challenging work, responsibility, recognition and achievement as motivators. Hence, the job satisfaction construct can be considered to be a function of work-related rewards and work values. 


\section{ORGANIZATIONAL COMMITMENT}

The concept of organizational commitment has been defined in many ways. Steers (1977) is among the first to view organizational commitment as an employee attitude and as a set of behavioural intentions; the willingness to exert considerable effort on behalf of the organization and a strong desire to maintain membership of the organization. Then, Mowday, Steers and Porter $(1979 ; 1982)$ refined that the concept of organization commitment can be characterized by at least three factors: (a) a strong belief in, and acceptance of, the organization's goals and values, (b) a willingness to exert considerable effort on behalf of the organization; and (c) a strong desire to remain in the organization. The researchers defined organizational commitment as the strength of an individual's identification with the goals of an organization's multiple constituencies. It is about positive involvement which is integral to developing shared goals and objectives in a particular organization. Organizational commitment can be considered to be affective responses or attitudes which link or attach an employee to the organization.

During the last decade, it has become clear that organizational commitment is a multidimensional construct that involves three dimensions: affective, continuance and normative. This conceptualization of organizational commitment is commonly known as the Meyer and Allen's (1991) Three-Component Model of OC. Affective commitment refers to the employee's emotional attachment to the organization. Employees with strong affective commitment remain with the organization because they want to do so. Continuance commitment refers to the extent to which the employee perceives that leaving the organization will be costly. Employees with strong continuance commitment remain because they have to do so. Finally, normative commitment refers to the employee's feelings of obligation to the organization and the belief that staying is the 'right thing' to do. Employees with strong normative commitment remain because they feel that they ought to do so (Meyer and Allen, 1991). The most desirable profile of organizational commitment amongst employees, especially those involved in the services industry which demands continuous good service, is affective commitment which is the most prevalent theme in the Meyer and Allen (1991) model. This study focused on the affective commitment dimension that captures the degree of affective or emotional attachment of employees in the service industry to the organizations.

Later, a revision of the three scales was undertaken (Meyer, Allen and Smith, 1993). Taking the cue from Allen and Meyer (1996) which revealed satisfactory construct validity and internal reliability, Meyer et al. (2002) conducted a meta analysis of the antecedents, correlates and consequences of the Three-Component Model of OC. They discovered that the model seems to be the most suitable conceptualization of organizational commitment and may indeed be applicable in other countries and cultures outside North America. In this respect, a recent study by Chin and Sheehan (2004) of 500 managers in Malaysia provides evidence of a three-component structure of organizational commitment as conceptualized by Meyer and Allen (1991).

Meanwhile, the significance and importance of the concept of organizational commitment in terms of leading to beneficial organizational and desirable outcomes such as increased 
effectiveness, reducing absenteeism and turnover, has been documented by many studies such as those of Steers (1977); Porter et al. (1974); Reiches (1985) and Tett and Meyer (1993). These positive linkages between organizational commitment and desirable organizational outcomes may be due to the findings by Hrebiniak and Alutto (1972) as well as Angle and Perry (1983) that organizational commitment is considered to be the result of an individual-organization relationship, where individuals attach themselves to the organization in return for certain valued rewards or payments from the organization. Hence, it is likely that job satisfaction is a dominant factor influencing organizational commitment of employees.

\section{Age as a Moderator Between Job Satisfaction and Organizational Commitment}

Most studies have found a positive relationship between age and job satisfaction (Kong et al., 1993; Weaver, 1977; Hulin and Smith, 1967). However, some recent evidence suggests that the assumed direct relationship between age and job satisfaction may be questionable. Older employees may experience a downturn in job satisfaction, suggesting a curvilinear relationship between age and job satisfaction (Luthans and Thomas, 1989; Zeitz, 1990; Kacmar and Ferris, 1989;). Meanwhile, there are some other past studies suggesting that job satisfaction may be independent of age (Wright, 1987) or may be inversely related to age (Ghazali, 1979).

Age has also been shown to have a positive relationship with organizational commitment. This may be due to the logic that as workers grow older, alternative employment opportunities become limited, making their current jobs more attractive (Mathieu and Zajac, 1990). Russ and McNeilly, (1995) discovered that the commitment of younger workers is likely to be more affected by disappointment with pay and promotion opportunities than is the commitment of older employees who have achieved their advancement and income potential compared to younger employees who often make job choices on the basis of income and career potential. Older employees, on the other hand, have higher needs for affiliation and lower needs for achievement (Doering, Rhoedes and Schuster, 1983). The older workers highly value close friendship with their fellow co-workers to provide emotional support for them to cope with various adverse life events (Schulz and Ewen, 1993) and they view the organization as a source of social satisfaction due to the strong social ties that have been established with the other members (Balfour and Weschsler, 1996). The difference of values held by older and younger employees which affects their level of organizational commitment is consistent with the views by Maslow (1970) that middle-age employees is devoted to the fulfillment of social needs whereas young adulthood is consumed by the need for economic security. Hence, it may be reasonable to view age as moderating the relationship between job satisfaction and affective commitment. 


\section{METHODOLOGY}

\section{Setting}

This study focuses on the Sarawak Tourism Board, tourist spots, travel agents, tour operators and hotels in Sarawak. The state of Sarawak was chosen as it is the one of the most popular tourist destination in Malaysia and has been positioned as offering the unique Borneo Paradise experience to tourists from the Asia Pacific region.

\section{Sample and Procedure}

The population is defined as all the employees involved in the tourism industry, especially the Sarawak Tourism Board, tourist spots, travel agents, tour operators and established hotels in Sarawak with ranking of at least three (3) stars. A total of 100 questionnaires were assigned to each human resource manager of about six organizations with instructions that the questionnaires should be allocated evenly to employees from various levels such as managerial, executives/supervisors and general staff. The selection of this sample was based on simple random sampling. A total of 99 responses were obtained, representing a response rate of about $16.5 \%$. About $53 \%$ of the employees were above 35 years old while $40 \%$ of them were below 35 years old. For the purpose of this study, younger employees were defined as those whose age is below 30 years whereas older employees were those whose age is above 35 years.

In terms of ethnicity, the sample consisted of Chinese (31\%), Malays (13\%) and other indigenous groups (55\%). About $69 \%$ of them were married while $30 \%$ were singles. With regards to gender, $51 \%$ of the respondents were males with the remaining $46 \%$ being females. Based on the educational qualification, the majority of the sample $(67 \%)$ had secondary or lower qualifications while $26 \%$ of them had diploma qualification and only $6 \%$ had degree qualifications. In terms of position, $11 \%$ were managers, $41 \%$ were executives, $21 \%$ were supervisors and $24 \%$ were general workers. Employees with more than 10 years of experience working in their respective organizations constituted 30\%, 2-5 years (29\%), 610 years $(25 \%)$, and one year and below (15\%). In terms of salary, the majority of the sample (80\%) had a monthly income of less than RM2,000.

\section{Research Instrument}

The independent variable in this study is job satisfaction. Job satisfaction was measured using the Job Descriptive Index (JDI), designed to measure five aspects of a job, namely, pay, promotion, supervision, and co-workers and the work itself (Smith et al., 1969). Respondents were asked to indicate whether a word or phrase describing a particular aspect of their job is applicable. The scores for each facet were computed by assigning 3 points for True, 1 point for Unsure and 0 for False. The total scores for each facet of job satisfaction ranges from 0 to 54 . 
The Cornell Job Descriptive Index (Cornell JDI) has been well accepted by many employees as a well formulated measurement tool which measures job satisfaction (Smith et al., 1969). Poon and Ainuddin (1990) has cited the work of Muchinsky (1977) that the JDI has been shown, by extensive research, to be a reliable and valid measure of job satisfaction. Nasurdin and Ramayah (2003) have found high internal reliability coefficient for the five facets of satisfaction, that is, pay (0.79), promotion (0.80), co-workers (0.84), supervision $(0.90)$ and work itself $(0.72)$. For this study, the reliability coefficient for the JDI scales was 0.7762 .

The dependant variable, organizational commitment, was measured using the revised Organizational Commitment Scales (Meyer, Allen and Smith 1993), that is, the Affective Commitment Scale (ACS), the Continuance Commitment Scale (CCS) and the Normative Commitment Scale (NCS) with 18 questions on five-point Likert scales. Four items were negatively phrased and had to be reverse-coded for analysis. Results for each dimension were summed and divided by 6 to arrive at a summary indicator of an employee's three dimensions of organizational commitment. The reliability coefficients for the three dimensions of organizational commitment were ACS scales (0.5693), CCS scales (0.5687), NCS scales (0.5957) while the overall reliability coefficient for all the 18 items of organizational commitment was 0.7339 .

The relatively high Cronbach's alpha values, which exceeded 0.70 for the instruments used to measure job satisfaction and organizational commitment, the exception being the ACS, CCS and NCS scales, indicated that the instruments used in this study were statistically reliable.

The Kovach (1946) ten job-related factors were used to determine what motivates the employees in the tourism industry in Sarawak, Malaysia. The ten work-related factors are good wages, tactful discipline, job security, interesting work, feeling of being involved, sympathetic help with personal problems, opportunities for advancement and development, good working conditions, personal loyalty to employees and appreciation, and praise for work done. The respondents were asked to indicate the degree of importance of the factors on a 5-point Likert scale towards creating a motivating job in the tourism industry. This instrument was used by Siu et al. (1997) in his studies of what motivates Hong Kong's hotel employees. It was reported that the instrument was used in one of the most widely known surveys for job satisfaction studies in the tourism industry in the United States and Canada.

\section{Data Analysis}

The SPSS statistical package was used to analyze the data. Given that organizational commitment can be influenced by personal factors (Mowday, Porter and Steers, 1982), six demographic factors were statistically controlled: position, education, salary, marital status, race and gender. A four-step hierarchical regression procedure was used to test the hypotheses of the study (Cohen and Cohen, 1975). Control variables (excluding age) were entered in the first step, followed by the main effects of job satisfaction and, subsequently, age in the third step. In the final step, the five interaction terms (job satisfaction facets by 
age) were loaded into the equation. The Pearson's correlation coefficients were used to analyze the relationship between each of the job satisfaction facets and organizational commitment. Kovach's (1946) ten job-related factors were ranked according to the order of importance in motivating the employees.

\section{FINDINGS}

The mean value for each of the five facets of job satisfaction varies from 25.9 to 38.3, out of a maximum score of 54. This suggests that the employees are moderately satisfied towards the various facets of job satisfaction. Out of a maximum score of five, affective commitment, continuance commitment and normative commitment had a mean value of $4.99,4.33$ and 4.62 respectively. This suggests that the employees have a relatively high score in the three dimensions of organizational commitment. Table 1 presents the means and standard deviations of the study variables.

Table 1. Total Scores for Satisfaction Facets, Means Scores for Commitment Scales and Standard Deviations of Study Variables.

\begin{tabular}{lcc}
\hline Variables & $\begin{array}{r}\text { Total Scores/ } \\
\text { Mean }\end{array}$ & Std Deviation \\
\hline Satisfaction with Work & 34.6 & 7.9 \\
Itself & 31.1 & 11.2 \\
Satisfaction with & 38.3 & 10.5 \\
Promotion & 25.9 & 9.8 \\
Satisfaction with & 38.1 & 12.6 \\
Supervision & & \\
Satisfaction with Pay & & \\
Satisfaction with Co- & & \\
workers & & \\
& 4.9 & 0.9 \\
Affective Commitment & 4.3 & 0.9 \\
Continuance Commitment & 4.6 & 0.9 \\
Normative Commitment & &
\end{tabular}


Table 2 depicts the Pearson's correlation coefficients for the variables in the study.

Table 2. Correlation Coefficients for the Main Variables

\begin{tabular}{|c|c|c|c|c|c|c|c|c|}
\hline \multirow[b]{2}{*}{ Variables } & \multicolumn{8}{|c|}{ Correlation Coefficients } \\
\hline & 1 & 2 & 3 & 4 & 5 & 6 & 7 & 8 \\
\hline $\begin{array}{l}\text { 1. Affective } \\
\text { Commitment Scales }\end{array}$ & 1 & .020 & $.456^{* *}$ & .165 & $.245^{*}$ & $.226^{*}$ & $.350 * *$ & $.275^{* *}$ \\
\hline $\begin{array}{l}\text { 2. Continuance } \\
\text { Commitment Scales }\end{array}$ & .020 & 1 & $.537 * *$ & -.160 & -.057 & -.030 & -.021 & .015 \\
\hline $\begin{array}{l}\text { 3. Normative } \\
\text { Commitment Scales }\end{array}$ & $.456 * *$ & $.537 * *$ & 1 & .021 & .118 & $.273 * *$ & $.327 * *$ & $.234^{*}$ \\
\hline $\begin{array}{l}\text { 4. Satisfaction towards } \\
\text { the nature of work }\end{array}$ & .165 & -.160 & .021 & 1 & $200^{*}$ & $.318^{* *}$ & $.522 * *$ & $.469^{* *}$ \\
\hline $\begin{array}{l}\text { 5. Satisfaction towards } \\
\text { salary }\end{array}$ & $.245^{*}$ & -.057 & .118 & $.200 *$ & 1 & $.239 *$ & $.328^{*}$ & $.312 *$ \\
\hline $\begin{array}{l}\text { 6. Satisfaction towards } \\
\text { promotion } \\
\text { opportunities }\end{array}$ & $.226^{*}$ & -.030 & $.273 *$ & $.318 *$ & $.239 *$ & 1 & $.542 * *$ & $.457 * *$ \\
\hline $\begin{array}{l}\text { 7. Satisfaction towards } \\
\text { supervision }\end{array}$ & $.350 * *$ & -.021 & $.327 * *$ & $.522 * *$ & $.328 * *$ & $.542 * *$ & 1 & $.700 * *$ \\
\hline $\begin{array}{l}\text { 8. Satisfaction towards } \\
\text { co-workers }\end{array}$ & $.275^{* *}$ & .015 & $.234 *$ & $.469 * *$ & $.312 * *$ & $.457 * *$ & $.700 * *$ & 1 \\
\hline
\end{tabular}

Notes: * Correlation is significant at the 0.05 level (2-tailed). ** Correlation is significant at the 0.01 level (2tailed).

Table 2 suggests that all facets of job satisfaction except satisfaction towards the nature of work, had significant correlations $(\mathrm{p}<0.05)$ with affective commitment. Only satisfaction towards promotion opportunities, satisfaction towards supervision and satisfaction towards co-workers had significant correlations $(\mathrm{p}<0.05)$ with normative commitment. However, none of the facets of job satisfaction had significant correlations with continuance commitment.

Table 3 presents the relative importance of the Kovach's Ten Job-Related Factors (1946) towards creating a motivating job in the tourism industry. Data suggests that all the factors were important towards creating job motivation in the tourism industry (mean $>3$ out of a maximum score of 5).

Table 3. Relative Importance of the Kovach's 10 Factors

\begin{tabular}{lrr}
\hline Factors & Mean & Std. Deviation \\
\hline Good wages & 4.2222 & .81511 \\
Job security & 4.4845 & .67875 \\
Interesting work & 4.5670 & .53827 \\
Feeling of being involved & 4.3232 & .68256 \\
Sympathetic help with personal problems & 3.7053 & .88575 \\
Opportunities for advancement and development & 4.3939 & .78009 \\
Good working conditions & 4.3434 & .70221 \\
Personal loyalty to employees & 4.2268 & .65360 \\
Appreciation and praise for work force & 4.1856 & .76825 \\
\hline
\end{tabular}


Table 4 depicts the results of the regression analysis for the dependent variable affective commitment.

Table 4. Hierarchical Regression Analysis on Dependent Variable - Affective Commitment

\begin{tabular}{|c|c|c|c|c|}
\hline Independent Variable & $\begin{array}{c}\text { Std Beta } \\
\text { Step 1 } \\
\text { (Model 1) }\end{array}$ & $\begin{array}{c}\text { Std Beta } \\
\text { Step 2 } \\
\text { (Model 2) }\end{array}$ & $\begin{array}{c}\text { Std Beta } \\
\text { Step 3 } \\
\text { (Model 3) }\end{array}$ & $\begin{array}{c}\text { Std Beta } \\
\text { Step 4 } \\
\text { (Model 4) }\end{array}$ \\
\hline $\begin{array}{l}\text { Control Variables } \\
\text { Position } \\
\text { Highest qualification } \\
\text { Monthly salary } \\
\text { Marital Status } \\
\text { Race } \\
\text { Gender } \\
\text { Years working in hotel }\end{array}$ & $\begin{array}{c}0.057 \\
-0.376^{* *} \\
0.242 * \\
-0.225 \\
0.207 \\
-0.202 \\
-0.076 \\
\end{array}$ & $\begin{array}{l}0.085 \\
-0.354 * * \\
0.045 \\
-0.251^{*} \\
0.194 \\
-0.193 \\
0.138 \\
\end{array}$ & $\begin{array}{l}0.071 \\
-0.364 * * \\
0.578 \\
-1.889 \\
1.697 \\
-1.840 \\
1.168 \\
\end{array}$ & $\begin{array}{c}0.114 \\
-0.253 \\
0.094 \\
-0.207 \\
0.197 \\
-0.241 \\
0.299 * \\
\end{array}$ \\
\hline $\begin{array}{l}\text { Model Variables (IV) - } \\
\text { Direct Effects } \\
\text { Satisfaction with the } \\
\text { nature of work } \\
\text { Satisfaction towards salary } \\
\text { Satisfaction towards } \\
\text { promotion } \\
\text { Satisfaction towards } \\
\text { supervision } \\
\text { Satisfaction towards co- } \\
\text { workers }\end{array}$ & & $\begin{array}{c}0.053 \\
0.274 * \\
-0.031 \\
0.079 \\
0.063\end{array}$ & $\begin{array}{c}0.046 \\
\\
0.265^{*} \\
-0.007 \\
0.251 \\
-0.059\end{array}$ & $\begin{array}{r}0.553 \\
\\
-0.943 \\
-0.940 \\
0.163 \\
-0.006\end{array}$ \\
\hline $\begin{array}{l}\text { Moderating Variable } \\
\text { Age }\end{array}$ & & & -0.101 & -0.919 \\
\hline $\begin{array}{l}\text { Interactions Effects } \\
\text { Work x Age } \\
\text { Salary x Age } \\
\text { Promotion x Age } \\
\text { Supervision x Age } \\
\text { Co-worker x Age }\end{array}$ & & & & $\begin{array}{r}-0.476 \\
1.227 \\
1.142 \\
0.029 \\
-0.055\end{array}$ \\
\hline $\begin{array}{l}\mathrm{R}^{2} \\
\text { Adj } \mathrm{R}^{2} \\
\mathrm{R}^{2} \text { Change } \\
\text { F Change }\end{array}$ & $\begin{array}{l}0.210 \\
0.144 \\
0.210 \\
3.159 * *\end{array}$ & $\begin{array}{l}0.351 \\
0.252 \\
0.141 \\
3.391 * *\end{array}$ & $\begin{array}{l}0.355 \\
0.247 \\
0.004 \\
0.477\end{array}$ & $\begin{array}{l}0.394 \\
0.243 \\
0.039 \\
0.923\end{array}$ \\
\hline
\end{tabular}

Note: * $\mathrm{p}<0.05,{ }^{* *} \mathrm{p}<0.01$

It was discovered that the control variables (position, highest qualification, monthly salary, marital status, race, gender and years working in hotel) explained $21 \%$ variation in affective commitment. From the first equation, highest academic qualification was found to have a 
significant negative relationship with affective commitment $(\beta=-0.376, p<0.01)$. Meanwhile, monthly salary also had a significant positive relationship with affective commitment $(\beta=0.242, \mathrm{p}<0.05)$. When the model variables were added, the additional variance explained was $14.1 \%$ ( $\mathrm{F}$ change $=3.391, \mathrm{p}<0.01$ ). A closer look at the model variables showed that only satisfaction towards salary $(\beta=0.274, p<0.05)$ was found to have a significant positive relationship with affective commitment. This finding provided support for hypotheses H1a. In sum, H1 is partially supported. The regression coefficient for age was not significant, indicating that age has no direct influence on affective commitment. On examining the specific interaction terms, age was not found to moderate the relationships between the five facets of job satisfaction and affective commitment. These findings did not provide support for $\mathrm{H} 2$. When age was entered, the incremental variance in affective commitment was only $0.4 \%$ and when the five interactions terms were finally entered, the incremental variance in affective commitment was only $3.9 \%$. The $\mathrm{F}$ change statistic for model 3 and model 4 was also not significant at the 5\% significant level.

The same four-step hierarchical regression analysis was conducted on the other two dimensions of organizational commitment, namely, continuance commitment and normative commitment to answer the fourth objective of this study by substituting the dependent variable in the model.

When continuance commitment was entered as the dependent variable, the control variables in model 1 explained $46.2 \%$ of the variance and when the model variables were entered into model 2 , the incremental variance explained was only $2.2 \%$. All the five facets of job satisfaction did not show a significant relationship with continuance commitment. Age did not have a direct influence on continuance commitment in model 3 while incremental variance explained was only $0.2 \%$. Similarly, no significant interaction effect between the facets of job satisfaction and age on continuance commitment was found in this study while incremental variance explained was only $3.2 \%$. The $\mathrm{F}$ change statistic was also not significant at the $5 \%$ level.

When normative commitment was entered as the dependent variable, model 1 explains $35.2 \%$ of the variance and when the model variables were entered into model 2, the incremental variance explained was only $10.2 \%$. Also, satisfaction towards supervision was the only one which showed a significant relationship with normative commitment $(\beta=$ $0.355, \mathrm{p}<0.05)$. The $\mathrm{F}$ change statistic was also significant $(\mathrm{F}$ change $=2.919, \mathrm{p}<0.05)$. Age did not have a direct influence on normative commitment in model 3 while incremental variance explained was only $0.3 \%$. In model 4 , age was also found not to have a direct effect on normative commitment. When the interaction effects were entered, the incremental variance explained was $15.3 \%$ ( $\mathrm{F}$ change $=5.671, \mathrm{p}<0.01)$.

The study also employed the procedures recommended by Baron and Kenny (1986) to test whether age (the mediator) moderates the relationship between each of the five facets of job satisfaction (independent variables) and the three dimensions of organizational commitment (dependent variables). First, the mediator is regressed on the independent variables; second, the dependent variable is regressed on the independent variable; and finally the dependent 
variable is regressed simultaneously on the independent and mediator variables. Mediation is present if all the following conditions hold true: the independent variable affects the mediator variable in the first equation; the independent variable affects the dependent variable in the second variable; the mediator affects the dependent variable in the third equation; full mediation occurs if the independent variable has no significant effect when the mediator is in the equation and partial mediation occurs if the effect of the independent variable is smaller but significant when the mediator is in the equation. This method failed to show statistically that age moderates the relationship between each of the five facets of job satisfaction and the three dimensions of organizational commitment as the findings above showed that not all the conditions hold true.

\section{DISCUSSION AND CONCLUSION}

The study identified that all 10 factors of the Kovach's Ten Job -Related Factors (1946) were important towards creating job motivation for employees in the tourism industry in Sarawak, Malaysia. The three most important factors are interesting work, job security and opportunities for advancement and development. Only satisfaction towards salary was found to have a significant positive relationship with affective commitment. This finding is consistent with those of previous researches which showed that job satisfaction has a positive impact on employees' commitment to the organization (Mottaz, 1987; Vanderberg and Lance, 1992; Knoop, 1995; Young et al., 1998; Testa, 2001; Nasurdin and Ramayah, 2003). It is plausible that when employees judged the organization to be fair in paying salaries which are competitive and motivates them to give good service to the customers, positive feelings of well being will be created. This, in turn, is likely to stimulate them to reciprocate by increasing their loyalty to the organization. Age had no direct and interactive influence on affective commitment. Hence, managers need not be concerned with the influence of employees' age to moderate the relationships between the five facets of job satisfaction and affective commitment.

All the five facets of job satisfaction did not show significant relationships with continuance commitment. Age did not have a direct influence on continuance commitment. Similarly, no significant interaction effect between facets of job satisfaction and age on continuance commitment was found in this study.

Only satisfaction towards supervision showed a significant positive relationship with normative commitment. It is plausible that when employees judge the organization to be providing good supervision, positive feelings of well being will be created. This is likely to stimulate them to reciprocate by increasing their sense of obligation to the organization and the belief that staying is the 'right thing' to do to the organization. Age also did not have a direct effect and interaction effect with the facets of job satisfaction to predict normative commitment.

This study has endeavoured to make both a theoretical and practical contribution to the existing literature by examining the influence of the job satisfaction and organizational 
commitment for employees in the tourism industry in Sarawak, Malaysia and to suggest some managerial implications.

\section{REFERENCES}

Allen, N.J. and Meyer, J.P. (1996). Affective, Continuance and Normative Commitment to the Organization: An Examination of Construct Validity. Journal of Vocational Behaviour, 49(3), 252276.

Angle, H.L. and Perry, J.L. (1983). Organizational Commitment: Individual and Organizational Influences. Work and Occupations, 10, 123-146.

Balfour, D.L. and Weschler, D. (1996). Organizational Commitment: Antecedents and Outcomes in Public Organizations. Public Productivity and Management Review, 19(3), 256-277.

Baron, R.M. and Kenny, D.A. (1986). The Moderator-Mediator Distinction in Social Psychological Research: Conceptual, Strategic and Statistical Considerations. Journal of Personality and Social Psychology, 51, 1173-1182.

Chin, K.K. and Sheehan, B. (2004). An Assessment of the Multidimensionality of Organizational Commitment in Malaysia. Malaysian Management Review, 39(2), 11-23.

Cohen, J. and Cohen P. (1975). Applied Multiple Regression/Correlation Analysis for the Behavioral Sciences. New Jersey: Lawrence Erlbaum Associates.

Doering, M., Rhoedes, S.R. and Schuster, M. (1983). The Aging Worker. Beverly Hills, California: Sage.

Ghazali bin Othman (1979) An Investigation of the Sources of Job Satisfaction of Malaysian School Teachers. PhD Thesis: University of California, Los Angeles.

Herzberg, F., Mausner, B. and Snyderman, B.B. (1959). The Motivation to Work. $2^{\text {nd }}$ Edition. New York: John Wiley and Sons, Inc.

Heskett, J.L., Jones, T.O., Loveman, G.W., Sasser, W.E. and Schlesinger, L.A. (1994). Putting the Service Profit Chain to Work. Harvard Business Review, March-April 1994.

Hoppock, R. (1935). Job Satisfaction. New York: Harper and Brothers.

Hrebiniak, L.G. and Alutto, J.A. (1972). Personal and role-related factors in the development of organizational commitment. Administrative Science Quarterly, 17(4), 555-573.

Hulin, C.L. and Smith, P.H. (1967). An Empirical Investigation of Two Implications of The Two Factor Theory of Job Satisfaction. Journal of Applied Psychology, 51(5), 396-407.

Kacmar, K.M. and Ferris, G.R. (1989) Thereotical and Methodological Considerations in the Age-Job Satisfaction Relationship. Journal of Applied Psychology, 74(2), 201-207. 
Knoop, R. (1995). Relationships between Job Involvement, Job Satisfaction and Organizational Commitment for Nurses. Journal of Psychology Interdisciplinary and Applied Psychology, 129(6), 643-649.

Kong, B.A., Chye, T.G. and Hian, C.K. (1993). Research Notes: The Impact of Age on the Job Satisfaction of Accountants. Personnel Review, 22(1), 31-39.

Kovach, K.A. (1946). Foreman Facts. New York: Labor Relations Institute of New York.

Locke, E.A. (1969). What is Job Satisfaction. Organizational Behaviour and Human Performance, 4 , 309-336.

Locke, E.A. (1976). The Nature and Causes of Job Satisfaction in M. D. Dunnette, Handbook of Industrial and Organizational Psychology, Chicago: Rand McNally College Publishing Company: pp. 1297-1349.

Lovelock, C. and Wright, L. (2002). Principles of Service Marketing and Management. $2^{\text {nd }}$ Edition. New Jersey: Prentice Hall.

Luthans, F. and Thomas L.T. (1989). The Relationship Between Age and Job Satisfaction. Personnel Review, 18(1), 23-26.

Maslow, A. (1970). Motivation and Personality. $2^{\text {nd }}$ Edition. New York: Harper \& Row.

Mathieu, J.E. and Zajac, D.M. (1990). A Review and Meta-Analysis of the Antecedents, Correlates and Consequences of Organizational Commitment. Psychological Bulletin, 108(2), 171-194.

Meyer, J.P. and Allen, N.J. (1984). Testing the " side-bet theory" of Organizational Commitment: Some Methodological Considerations. Journal of Applied Psychology, 69(3), 372-378.

Meyer, J.P. and Allen, N.J. (1991). A Three-Component Conceptualization of Organizational Commitment. Human Resource Management Review, 1(1), 61-89.

Meyer, J.P., Allen, N.J. and Smith, C.A. (1993). Commitment to Organizations and Occupations: Extension and Test of a Three-Component Conceptualization. Journal of Applied Psychology, 78(4), 538-551.

Meyer, J.P., Stanley, D.J., Herscovitch, L. and Topolnytsky, L. (2002). Affective, Continuance and Normative Commitment to the Organization: A Meta Analysis of Antecedents, Correlates and Consequences. Journal of Vocational Behaviour, 61(1), 20-52.

Mottaz, C.J. (1987). An Analysis of the Relationship between Work Satisfaction and Organizational Commitment. The Sociological Quarterly, 28(4), 541-558.

Mowday, R.T., Porter L.W. and Steers, R.M. (1982). Employee-Organizational Linkages: The Psychology of Commitment, Absenteeism and Turnover. New York: Academic Press.

Mowday, R.T., Steers, R.M. and Porter, L.W. (1979). The Measurement of Organizational Commitment. Journal of Vocational Behaviour, 14, 224-247. 
Nasurdin, A.M. and Ramayah, T. (2003). The Link Between Satisfaction and Commitment: Is It Different For Old And Young Workers? The National Human Resource Development Conference Proceedings, $15^{\text {th }}-16^{\text {th }}$ December 2003, Kuching, Malaysia.

Poon, M.L. and Ainuddin, A.R.O. (1990). Relationships Between Perceived Organisational Climate And Job Satisfaction And Performance. Malaysian Management Review, 25(1).

Porter, L.H., Steers, R.M. and Boulian P.V. (1974). Organizational commitment, Job Satisfaction and Turnover Among Psychiatric Technicians. Journal of Applied Psychology, 59(5), 603-609.

Reichers, A.E. (1985). A Review and Reconceptualization of Organizational Commitment. Academy of Management Review, 10(3), 465-476.

Russ, F.A. and McNeilly, K.M. (1995). Links among satisfaction, commitment and turnover intentions: The moderating effect of experience, gender and performance. Journal of Business Research, 34, 57-65.

Schulz, R. and Ewen, R.B. (1993). Adult Development and Aging: Myths and Emerging Realitie., $2^{\text {nd }}$ Edition. New York: Macmillan Publishing Company.

Simons, T. and Enz, C.A. (1995). Motivating Hotel Employees. Cornell Hotel and Restaurant Administration Quarterly, 36(1), 20-27.

Siu, V., Tsang, N. and Wong, S. (1997). What Motivates Hong Kong's Hotel Employees? Cornell Hotel and Restaurant Administration Quarterly, 38(5), 44-49.

Smith, P.C., Kendall, L.M. and Hulin, C.L. (1969). The Measurement of Satisfaction in Work and Retirement. Chicago: Rand McNelly.

Steers, R.M. (1977). Antecedents and Outcomes of Organizational Commitment. Administrative Science Quarterly, 22, 46-56.

Steinhaus, C.S. and Perry, J.L. (1996). Organizational Commitment: Does sector matter? Public Productivity and Management Review, 19(3), 278-288.

Testa, M.R. (2001). Organizational Commitment, Job Satisfaction and Effort in the Service Environment. Journal of Psychology, 135(2), 226-236.

Tett, R.P. and Meyer, J.P. (1993). Job Satisfaction, Organizational Commitment, Turnover Intention and Turnover: Path Analyses Based On Meta-Analytic Findings. Personnel Psychology, 46, 259-293.

Vandenberg, R.J. and Lance, C.E. (1992). Examining the Causal Order of Job Satisfaction and Organizational Commitment. Journal of Management, 18(1), 153-167.

Weaver, C.N. (1977). Relationships among pay, race, sex, occupational prestige, supervision, work autonomy, and Job Satisfaction in a National Sample. Personnel Psychology, 30, 437-445.

Williams, L.J. and Anderson, S.E. (1991). Job Satisfaction and Organizational Commitment as Predictors of Organizational Citizenship and In-role Behaviours. Journal of Management, 17(3), 601-617. 
Wright, Jr. R., King, S.W., Berg, W.E. and Greecy, R.F. (1987). Job Satisfaction Among Black Female Managers: A Causal Approach. Human Relations, 40, 489-506.

Young, B.S., Worchel, S. and Woehr, D. (1998). Organizational Commitment among Public Service Employees. Public Personnel Management, 27(3), 339-348

Zeitz, G. (1990). Age and Work Satisfaction in a Government Agency: A Situational Perspective. Human Relations, 43(5), 419-438. 